\title{
Tolerization of Inflammatory Gene Expression
}

\author{
John J. Seeley and SANKar GHosh \\ Department of Microbiology \& Immunology, Columbia University, \\ College of Physicians and Surgeons, New York, New York 10032 \\ Correspondence: sg2715@columbia.edu
}

\begin{abstract}
Lipopolysaccharide (LPS) is a potent inducer of inflammation. However, in a phenomenon known as LPS tolerance, prolonged exposure to LPS reprograms the host response to subsequent LPS reexposure. Proinflammatory cytokine production is suppressed, while production of antimicrobial genes is increased. In vivo models suggest that LPS tolerance dramatically reduces susceptibility to septic shock, while keeping the capacity for clearance of certain pathogens intact. These observations imply that artificial induction of tolerance may be an attractive means to intervene in the progression of sepsis and other inflammatory diseases. However, the underlying mechanisms that govern the tolerogenic response remain poorly understood, hindering efforts to evaluate LPS tolerance induction as a therapeutic approach. Recent advances indicate that chromatin modifications and microRNA mediators may be particularly important in the tolerogenic response. In this review, we discuss possible mechanisms to account for the phenomenon of LPS tolerance, with particular emphasis on the role of newly identified mediators.
\end{abstract}

Proper regulation of the inflammatory response is vital for organismal homeostasis. Failure to initiate innate immune responses leads to pathogen invasion, but systemic production of inflammatory cytokines (sepsis) can result in lethal septic shock (Soong and Soni 2012). It is estimated that 751,000 cases of sepsis occurred in the USA in 1995 , with a mortality rate of $28.6 \%$; deaths related to sepsis accounted for $9.3 \%$ of all deaths in the country that year (Angus et al. 2001). The hospitalization rate for septicemia or sepsis has doubled between 2000 and 2008, and costs of treatment have been rising (Hall et al. 2011). New immunomodulatory treatment options are therefore highly desirable.

Sterile injection of lipopolysaccharide (LPS, a component of bacterial cell walls) into animals can model the febrile responses and lethality of septic shock, demonstrating that these symptoms are not dependent on live infection. Rather, they are the result of the release of cytokines, including TNF- $\alpha$ (Tracey et al. 1986; Rothe et al. 1993), IL-1 $\beta$ (Li et al. 1995), and IL-6 (Chai et al. 1996), by macrophages (Freudenberg et al. 1986). Interestingly, animals challenged with low doses of LPS become "tolerant," and can survive rechallenge with up to 10 times a normally lethal LPS dose (Carey et al. 1958). Paradoxically, LPS-tolerant animals also show reduced pathogen loads and increased survival after subsequent infection with bacteria or fungi (Rayhane et al. 2000; Lehner et al. 2001a; Wheeler et al. 2008), which may be partially due to reprogramming of the macrophage LPS response (Foster et al. 2007). Artificial induction of such a tolerant state in patients therefore seems to be an attractive means of treating septic infection.

However, a molecular explanation for LPS tolerance has remained elusive, leaving few options for the design and testing of tolerogenic therapies. This is despite many advances that have been made in understanding the response of untolerized macrophages to LPS exposure. Recent work suggests that chromatin complexes may play a large role in shaping the magnitude, duration, and patterns of gene expression in the LPS response. Here, the potential of chromatin modifications to regulate LPS-induced gene expression in both naïve and tolerant cells is discussed, and novel mechanisms of chromatin regulation and potential therapeutic targets are described.

\section{LPS RECOGNITION AND NF-кB ACTIVATION}

Toll-like receptor 4 (TLR4) is the cell-surface receptor for LPS, which must be bound with the host protein MD2 for recognition. CD14 is also required as a coreceptor for full LPS signaling to occur (Jiang et al. 2005). LPS binding induces signaling through MyD88, IRAK, and TRAF family members, which activates the inhibitor of $\kappa \mathrm{B}$ (IкB) kinase (IKK) complex, which leads to the phosphorylation, ubiquitination, and proteasomal degradation

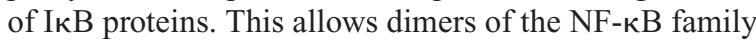
of transcription factors, that were retained in the cytosol through interaction with IkBs, to translocate into the nucleus and bind specific recognition sequences in the genome (referred to as $\mathrm{\kappa B}$ sites) to modulate transcription. Other inflammatory stimuli, such as peptidoglycan, IL-1, and TNF- $\alpha$, also activate the IKK complex in macrophages, although they signal through different receptors and only partially overlapping signaling pathways (Hayden and Ghosh 2012).

Although NF- $\mathrm{\kappa B}$ is often discussed as a single molecule, it actually consists of a hetero- or homodimer of five possible subunits (p65/RelA, p50/NFKB1, c-Rel, RelB, and $\mathrm{p} 52 / \mathrm{NFKB} 2$ ), each of which contains a Rel homology domain responsible for DNA binding. However, only 
three of the subunits (p65, c-Rel, and RelB) contain a carboxy-terminal transactivation domain (TAD) required to initiate transcription, so the dimer composition determines the ultimate effect of NF- $\mathrm{BB}$ binding to a gene promoter. Typically, activation of macrophages leads to binding of dimers containing p65 or c-Rel to NF- $\kappa$ B target genes, and the triggering of gene expression. However, p50:p50 homodimers can prevent transcription by competing for promoter binding (p50 lacks a TAD), and RelB-containing dimers can either repress or activate gene expression (Hoffmann et al. 2006).

Even though the major signaling intermediates and $\mathrm{NF}-\kappa \mathrm{B}$ recognition sites have been identified, whether a particular NF-кB-dependent gene will be expressed, and at what levels, after LPS stimulation remains hard to predict. This is especially true after LPS tolerization.

\section{LPS TOLERANCE ALTERS GENE EXPRESSION PATTERNS DOWNSTREAM FROM TLR4 SIGNALING}

\section{LPS Tolerance In Vivo}

It has been noted for over half a century that animals exposed to low doses of endotoxin can tolerate subsequent exposure to extremely high doses of LPS. LPSinduced febrile responses (Morgan 1941; Favorite and Morgan 1942; Beeson and Technical Assistance of Elizabeth 1947) and metabolic changes (Lang and Spitzer 1987) are reduced after tolerization. Lethality from septic shock is also reduced (Carey et al. 1958), suggesting that this may be a protective response.

Surprisingly, this protection does not necessarily come at the cost of lowered resistance to infection. Tolerized mice show reduced pathogen load and increased survival after subsequent induction of polymicrobial sepsis (by cecal ligation and puncture [Wheeler et al. 2008]) or infection by Cryptococcus neoformins (Rayhane et al. 2000) or Salmonella enterica (Lehner et al. 2001a). Baboons primed with an exposure to heat-killed bacteria before Escherichia coli infusion may also have better survival rates at the cost of increased lung damage, although this was not conclusively determined (Welty-Wolf et al. 1998). The benefit of tolerization in humans is less clear (Munoz et al. 1991; Munford and Pugin 2001).

The tolerization process is evolutionarily conserved and has been described in mice (Carey et al. 1958), rats (Fraker et al. 1988), rabbits (Morgan 1941; Beeson and Technical Assistance of Elizabeth 1947), guinea pigs (Roth et al. 1994), monkeys (Myers et al. 1974), and humans (Favorite and Morgan 1942). Even amongst human peripheral blood mononuclear cells isolated from different human individuals, the tolerization process is very robust despite large variability in initial cytokine production (Randow et al. 1995). Cell transfer experiments show that the tolerization process is dependent on macrophages (Freudenberg and Galanos 1988). Coculture systems, studies on cells derived from knockout mice, and transfer experiments confirm that IL-10, nitric oxide, TNF- $\alpha$, IFN- $\alpha / \beta, T$-, and B-cells are not required
(Berg et al. 1995; Lehner et al. 2001b; Wysocka et al. 2001).

Tolerance was originally proposed to be a state of hyporesponsiveness in macrophage activation by LPS. Evidence for this conclusion will be discussed below. However, the identification of LPS-responsive genes that become hyperresponsive after tolerization, as well as the phenomenon of cross-tolerance (discussed below) and studies of the Tn $f$ and $I l l b$ promoters in macrophages, suggest that tolerization involves large-scale reprogramming of gene expression, rather than a simple refractory period to stimulation.

\section{TLR4 Signaling and LPS Tolerance}

Macrophages stimulated with LPS in vitro also undergo tolerization, characterized by reduced transcription of many proinflammatory cytokines including $I l 6, I l 12 b$, and $I l l b$, as well as strongly reduced secretion of TNF$\alpha$ after further LPS stimulation (Zuckerman et al. 1989; Foster et al. 2007). This likely accounts for the decreased LPS-induced fever and lethality observed in tolerized animals. Higher pretreatment doses (generally in the range of $10 \mathrm{ng} / \mathrm{mL}-1 \mu \mathrm{g} / \mathrm{mL}$ LPS) and longer periods of initial stimulation time, up to $24 \mathrm{~h}$, reliably lead to a greater degree of tolerization of macrophages in vitro, as measured by the hyporesponsiveness of the above genes, although extremely low doses of LPS pretreatment can cause a priming effect on gene expression instead (Virca et al. 1989; Henricson et al. 1993; LaRue and McCall 1994; Foster et al. 2007).

Several groups have noted LPS signaling defects in tolerized cells, leading to the suggestion that LPS pretreatment causes a refractory state in TLR4 signaling. Reported changes include reductions in LPS-induced MyD88TLR4 association (Medvedev et al. 2002), IRAK activity (Nomura et al. 2000; Medvedev et al. 2002), ІкB $\alpha$ degradation (Medvedev et al. 2000, 2001), and p38 (Medvedev et al. 2000, 2001, 2002), ERK (Medvedev et al. 2000), JNK (Sato et al. 2000; Medvedev et al. 2001), and/or NF- $\kappa$ B activation (Medvedev et al. 2000, 2001, 2002; Nomura et al. 2000; Sato et al. 2000). This was variously hypothesized to be due to a reduction in cell-surface levels of TLR4 (Nomura et al. 2000; Bosisio et al. 2002), or an increase in expression of A20 (Xiong and Medvedev 2011; Xiong et al. 2011) or IRAK-M (Kobayashi et al. 2002), two LPS-inducible, negative regulators of TLR4 signaling (Fig. 1). However, overexpression of TLR4 in CHO cells does not restore signaling after tolerization (Medvedev et al. 2001), and reductions in surface TLR4 levels do not occur in human monocytes (Medvedev et al. 2002). Neither A20 (Boone et al. 2004) nor IRAK-M (Kobayashi et al. 2002) knockout cells are entirely incapable of tolerization, although sometimes delays are observed. This leaves the observed changes in signaling largely unexplained.

Furthermore, several groups have reported unaltered NF- $\kappa \mathrm{B}$ activation upon restimulation of tolerized cells (Haas et al. 1990; Ziegler-Heitbrock et al. 1994; Yoza et al. 2000; Porta et al. 2009). In a large number of stud- 
ies, $\operatorname{Tn} f$ transcripts are still found to be produced at normal (Zuckerman et al. 1989) or reduced, but clearly detectable levels (Virca et al. 1989; Wahlstrom et al. 1999; Medvedev et al. 2000, 2002), leading to the hypothesis that $\operatorname{Tnf}$ may be posttranscriptionally or posttranslationally repressed (Zuckerman et al. 1989), although this does not explain the transcriptional changes noted for other cytokines. This would imply that signaling to the nucleus remains at least partially intact in tolerized cells, and other critical regulators are involved in cytokine hyporesponsiveness.

\section{Cross-Tolerance}

The phenomenon of cross-tolerance is further an indication of the existence of tolerogenic mediators downstream from TLR4. Pretreatment with TLR2 agonists can also lead to tolerance to LPS, and vice versa (although occasionally tolerance will only work in one direction). Tested TLR2 agonists include MALP-2 (Sato et al. 2000), lipoarabinomannan (Medvedev et al. 2001), soluble tuberculosis factor (Medvedev et al. 2001), lipoteichoic acid (Lehner et al. 2001b), and zymosan (Zuckerman et al. 1989; Cavaillon et al. 1994). Crosstolerization between TNF and LPS, as well as IL-1 and LPS, also seems to occur in vivo and in vitro, although treatment with high doses of these cytokines are required to induce complete LPS tolerance (Fraker et al. 1988; Erroi et al. 1993; Cavaillon et al. 1994; Medvedev et al. 2000). This is not a general feature of stimulation, as IL-8 (Cavaillon et al. 1994) or IL-6 (Erroi et al. 1993; Cavail-

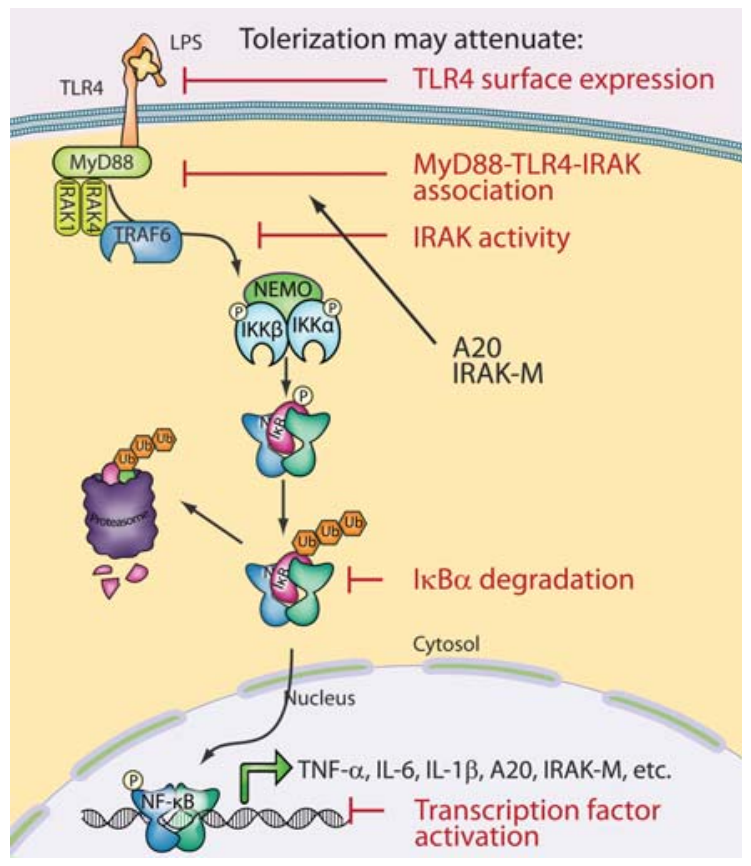

Figure 1. Changes in TLR4 signaling after tolerization. The LPS-TLR4 signaling pathway is depicted, and elements of the pathway that are sometimes attenuated in tolerized cells are highlighted. lon et al. 1994) pretreatment does not lead to tolerization. Cross-tolerization is not necessarily as dramatic in effect as LPS tolerance, as in some cases only a $50 \%$ reduction in TNF- $\alpha$ production has been reported. These observations, taken together with studies of the TLR4 signaling pathway after tolerization, would suggest that some shared signaling intermediates or factors downstream from NF- $\kappa \mathrm{B}$ activation are affected by tolerization.

\section{Hyperresponsive Genes in LPS Tolerance}

A complete loss of signaling also fails to explain one of LPS tolerization's most poorly understood features: while expression of damaging proinflammatory genes tends to be repressed in tolerized cells, antiinflammatory and antimicrobial genes are expressed at similar or higher levels upon restimulation. This phenomenon has been most clearly showed in a recent study using microarray and qPCR analysis (Foster et al. 2007). The existence of hyperresponsive antimicrobial genes may provide an explanation for the increased microbial clearance and survival that is observed when tolerance is induced before infection in mice (Rayhane et al. 2000; Lehner et al. 2001a; Wheeler et al. 2008). Genes that have been reported to become hyperresponsive after tolerization include Illrn (Randow et al. 1995), Tnfr-2 (Henricson et al. 1993), and perhaps Csf3 (Knopf et al. 1994), Vcam1 (Flohe et al. 1999), and $I l 10$ (Frankenberger et al. 1995; Flohe et al. 1999; Wysocka et al. 2001; Porta et al. 2009) (although, conflictingly, Il10 becomes hyporesponsive in some systems (Randow et al. 1995; Flach et al. 1997; Sato et al. 2000)). Thus, the same LPS input can lead to dramatically different gene expression outputs, clearly indicating the existence of tolerogenic mediators downstream from TLR4 signaling. This led to the suggestion that LPS tolerance actually involves reprogramming of the macrophage rather than simple hyporesponsiveness to LPS signaling.

\section{Studies of Tolerance and the Tnf and Il1b Promoters}

What regulators might allow the same input stimulus and signaling pathways to produce two (or more) dramatically different effects on gene expression? Studies of two early response genes, Tnf and $I l 1 b$, have led to the proposal of several distinct mechanisms of promoter regulation.

LPS stimulation of naïve THP1 cells leads to the loss of repressive $\mathrm{H} 3 \mathrm{~K} 9$ dimethylation at the Tnf (El Gazzar et al. 2007) and Il1b promoters (Chan et al. 2005; Chen et al. 2009). Demethylation does not occur in tolerized cells, and heightened expression of SIRT1, a histone and protein deacetylase, has been proposed to mediate this process by increasing expression and recruitment of the NF- $\kappa$ B subunit RelB to these promoter regions (Fig. 2B). RelB subsequently recruits the histone H3K9 methyltransferase G9a to these promoters, preventing H3K9 


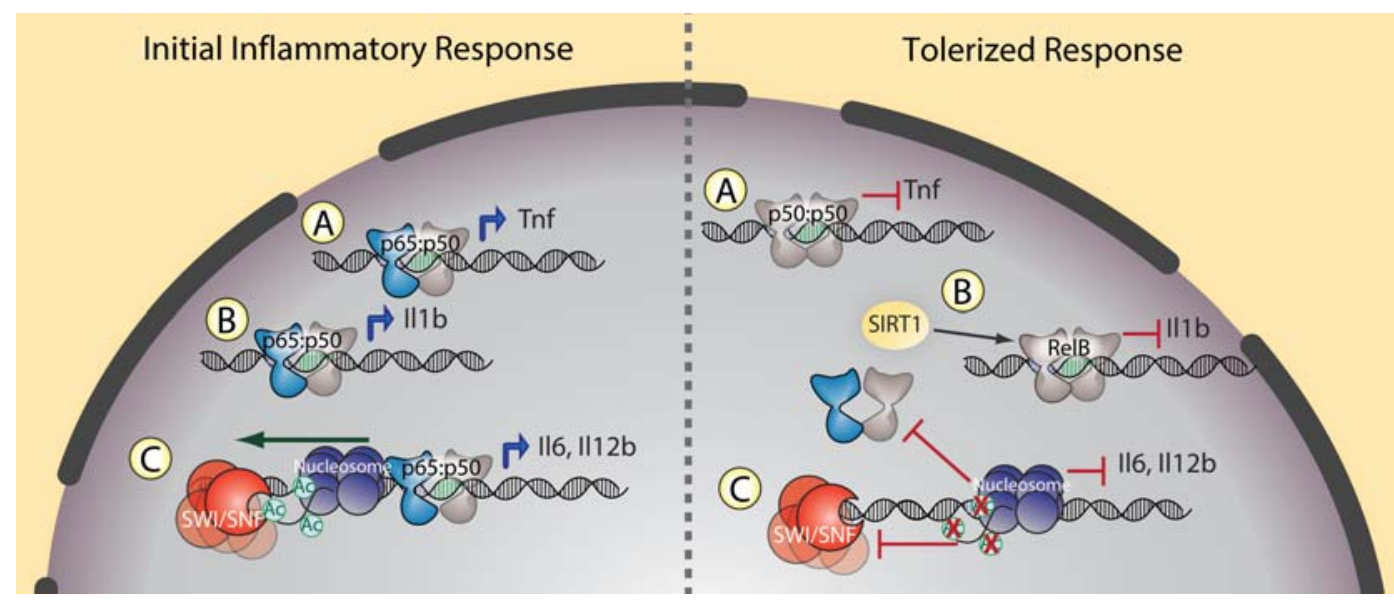

Figure 2. Changes in the nucleus after tolerization. Hyporesponsiveness of early response genes has been attributed to an exchange of p65:p50 NF-кB dimers for p50:p50 homodimers $(A)$, and SIRT1-mediated exchange of p65:p50 dimers for RelB-containing dimers $(B)$. Changes in expression of late response genes have been attributed to differential recruitment of the SWI/SNF complex, which is required for nucleosome remodeling and subsequent NF- $\mathrm{kB}$ binding to gene promoters. Hyporesponsive genes lose SWI/SNF complex recruitment after tolerization $(C)$. Conversely, hyperresponsive genes gain SWI/SNF complex recruitment after tolerization (not shown).

demethylation. G9a recruitment also leads to recruitment of heterochromatin protein 1 and the suppression of target-gene transcription. Silencing RelB expression increases p65 promoter binding and partially restores gene expression in tolerized cells, suggesting that it is of prime importance in this process (Yoza et al. 2006; El Gazzar et al. 2007; Chen et al. 2009; Liu et al. 2011a). SIRT1 is also capable of deacetylating histone H4K14 as well as lysine 310 of p65, thus further repressing residual p65 activity at targeted promoters after tolerization (Liu et al. 2011a).

Differential expression and utilization of the NF-кB subunit $\mathrm{p} 50$ has also been implicated in the hyporesponsiveness of Tnf transcription. NF-кB binding to the Tnf promoter has been detected after LPS stimulation of both naïve and tolerized Mono Mac 6 cells; however, it has been proposed that the complexes in tolerized cells are predominantly composed of p50/p50 homodimers, which cannot induce transcriptional activity (Fig. 2A) (Ziegler-Heitbrock et al. 1994). Increased p50 binding to $T n f$ and Ifnb promoter constructs after tolerization has been reported, which supports this hypothesis. Furthermore, macrophages from p50 knockout mice continue to produce TNF- $\alpha$ upon restimulation even after 18$20 \mathrm{~h}$ of LPS pretreatment, also suggesting that the p50 $\mathrm{NF}-\kappa \mathrm{B}$ subunit also plays a critical role in tolerance in addition to RelB (Bohuslav et al. 1998; Porta et al. 2009).

However, other findings do not support this conclusion, as genes were still found to become hyporesponsive after LPS pretreatment of RelB and p50 knockout macrophages (Wysocka et al. 2001). This further highlights the complexity of the tolerization process and the difficulty in finding a predominant tolerogenic mechanism. It is possible that multiple regulatory mechanisms, including some yet to be elucidated, are required to regulate the tolerogenic response at different times and conditions of stimulation.

\section{Tolerance and Late Response Genes}

Although Tnf and $I l l b$ have been studied in depth, it is important to note that these are both examples of early LPS response genes. Chromatin modifications, which include the covalent modification of histone tails and/or nucleosome repositioning, are involved in LPS-responsive gene expression. However, the exact modifications that are required vary greatly between the early and late response genes. Promoters of early response genes are kept in an open state even in unstimulated naïve macrophages, with constitutively high levels of histone H3 lysine acetylation and $\mathrm{H} 3 \mathrm{~K} 4$ trimethylation (modifications associated with transcription) (Ramirez-Carrozzi et al. 2006; Kayama et al. 2008), RNA polymerase II (Pol II) association (Hargreaves et al. 2009), and immediate accessibility to $\mathrm{p} 65$ (Saccani et al. 2001). Basally associated repressor complexes are required to prevent inappropriate transcription (Hargreaves et al. 2009).

This is in contrast to other genes rendered hyporesponsive by LPS tolerance, including $I l 6, I l 12 b$, and Nos 2 (involved in LPS-induced nitric oxide synthesis), which are a part of the late LPS response (Ramirez-Carrozzi et al. 2009). These genes require histone $\mathrm{H} 3$ lysine acetylation and trimethylation to be induced and much of the transcriptional machinery to be actively recruited for expression after stimulation of naïve cells (Ramirez-Carrozzi et al. 2006; Kayama et al. 2008). This is often dependent on the expression of genes transcribed during the early response. For instance, $I l 6$ and $I l 12 b$ transcription depends on the expression of the early response gene ІкB $\zeta$, which mediates H3K4 trimethylation and recruitment of p65, TATA-binding protein, and Pol II (Yamamoto et al. 2004; Kayama et al. 2008). Furthermore, late response genes often have promoters that are stably associated with nucleosomes, which block transcription factor access. Recruitment of the switching defective/sucrose nonfer- 
menting (SWI/SNF, also known as BAF) complex is required before recruitment of $\mathrm{p} 65$ and transcriptional machinery can occur (Weinmann et al. 1999; Saccani et al. 2001; Ramirez-Carrozzi et al. 2006, 2009).

It is highly likely that tolerization employs similar mechanisms to modify gene expression. That is, hyporesponsive early genes will be actively repressed to prevent inappropriate gene expression (by p50, RelB, or other factors), whereas late response genes will be regulated at the level of initiating factor recruitment. Indeed, it has been noted that Brg1, an enzymatic subunit of the SWI/ SNF complex, is differentially recruited at hyporesponsive and hyperresponsive gene promoters after tolerization. For example, at the promoters of Il6 and Lipg, two genes that become hyporesponsive to LPS, high Brg1 recruitment is noted only after stimulation of naïve, but not tolerized, cells (Fig. 2C). Conversely, Brg1 is only recruited at high levels to the promoter of the hyperresponsive gene Fprl after tolerization has occurred (Foster et al. 2007). Furthermore, interferon gamma pretreatment reduces LPS tolerization (Frankenberger et al. 1995) and prevents $I l 6$ from becoming hyporesponsive after lowdose tolerization of primary human monocytes. Intriguingly, this correlates with partially restored Brg1 and p65 recruitment to the Il6 promoter (Chen and Ivashkiv 2010). This additional regulatory layer may explain discrepancies seen between timing and LPS dosage required to tolerize the late response genes, including $I l 6$ (Chen and Ivashkiv 2010), Il12 (Wysocka et al. 2001), and Nos2 (Zhang and Morrison 1993), compared with the early response gene Tnf. However, the key regulators of SWI/ SNF recruitment (and any additional histone modifications required of late response genes in this process) remain to be identified.

\section{An Inclusive Model}

It is interesting to note that the hyperresponsive genes are not only expressed to a higher degree, but are also expressed very rapidly after tolerization (Foster et al. 2007). This may be important given the observation that $\mathrm{I} \kappa \mathrm{B} \alpha$ degradation in response to LPS stimulation is intact in tolerized THP1 cells, but ІкB $\alpha$ resynthesis after stimulation occurs faster than in naïve cells (LaRue and McCall 1994). This may suggest that the observed defects in TLR4 signaling of tolerized cells are not entirely irrelevant. Rather, it is possible that NF- $\kappa B$ activation is limited to transient pulses of activity after tolerization due to these and other changes in the TLR signaling cascade. Combined with an alteration in the prevalence of active NF- $\mathrm{BB}$ subunits, this may restrict the number of genes that can be expressed: Only genes that successfully undergo nucleosome repositioning and histone modification in the narrow window of $\mathrm{p} 65$ translocation will be successfully transcribed. Hyperresponsive genes that have already undergone modifications to more rapidly recruit $\mathrm{Brg} 1$ may then be more likely to be expressed or expressed at higher levels than other genes. Thus, the kinetics of NF- $\mathrm{\kappa B}$ activation as well as alterations in dimer equilibrium may reinforce changes in the Brg1 recruitment response, making the process of tolerization dependent on several partially redundant mechanisms for full effectiveness.

\section{microRNAs ARE POTENTIAL REGULATORS OF LPS TOLERIZATION}

microRNAs (miRNAs) have emerged as a new class of gene regulatory factors. miRNAs generally bind to mRNA transcripts based on sequence similarity, leading either to transcript degradation or the repression of translation (reviewed in Fabian and Sonenberg (2012); Pasquinelli (2012)). Although miRNAs sometimes have subtle effects on gene expression levels, by targeting mRNAs of key regulatory or rate-limiting proteins (or multiple components of a signaling cascade), they can have farreaching phenotypic effects under appropriate conditions (Bartel 2009). It is worth noting that, because miRNAs target mRNAs for inhibition, their downstream effects are dependent on protein turnover. This may make miRNAs conceptually well-suited for the regulation of delayed responses such as LPS tolerance.

\section{Induced Negative Regulators of the LPS Response}

Several miRNAs are regulated by NF-кB and function as classical negative-feedback regulators in macrophages. These miRNAs often remain down- or up-regulated for some time, and may thus contribute to tolerance. miR-146a, one of the best characterized examples, is up-regulated by LPS stimulation in macrophages and suppresses IRAK1 and TRAF6 levels, leading to attenuation of the response (Taganov et al. 2006). This miRNA continues to be highly expressed after tolerization, and may reinforce previously discussed tolerogenic mechanisms (Nahid et al. 2009; El Gazzar et al. 2011), although it cannot account for all aspects of tolerance. miR-146a knockout mice are hypersensitive to LPS-induced septic shock, confirming the relevance of miR-146a to LPSinduced inflammatory responses in vivo (Boldin et al. 2011).

LPS stimulation of human monocytes also leads to the up-regulation of miR-9, which was found to target NFKB1/p105 for translational repression, although the exact ramifications of this targeting on LPS signaling were not explored (Bazzoni et al. 2009). Let-7 family members are also up-regulated upon NF- $\mathrm{kB}$ activation. Because they have been found to regulate TLR4 expression (Chen et al. 2007; Androulidaki et al. 2009), they may contribute to tolerance in a manner similar to miR-146a. miR-147 is also up-regulated in response to LPS and inhibits NF- $\mathrm{kB}$ activation, although its mechanism of action is unclear (Liu et al. 2009). miR-98 has been found to repress IL-10 production and is down-regulated by LPS stimulation, giving it a role in antiinflammatory regulation (Liu et al. 2011b). Finally, miR-221, miR-579, and miR-125b have been found to be regulated by LPS stimulation and are involved in Tnf transcript degradation, which may further explain the strong hypo- 
responsiveness of Tnf in particular (El Gazzar and McCall 2010). The regulation and effects of these and other miRNAs are summarized in Table 1.

Interestingly, some LPS-induced miRNAs seem capable of differentially regulating the expression of large numbers of genes downstream from signaling. For example, miR-21 is induced by LPS within $4 \mathrm{~h}$, and expression is sustained at $24 \mathrm{~h}$ of stimulation. By targeting PDCD4, a regulator with roles in both $\mathrm{NF}-\kappa \mathrm{B}$ activation and selective inhibition of cap-dependent translation, miR-21 suppresses NF- $\mathrm{B}$ activation and transcription of $I l 6$, but simultaneously promotes production of IL-10 protein (Sheedy et al. 2010). If this capacity extends to other proteins, miR-21 could produce a response with both hypo- and hyperresponsive protein production. This does not directly account for the differences in LPS-induced gene transcription after tolerization, but could nonetheless contribute to the tolerance phenotype.

miR-132 is also up-regulated by LPS stimulation of human monocytes (Taganov et al. 2006; Bazzoni et al. 2009), and inhibits expression of p300, a transcriptional coactivator (Lagos et al. 2010). miR-187 is similarly in- creased, and down-regulates $\mathrm{I} \kappa \mathrm{B} \zeta$. This selectively decreases downstream Pol II recruitment to the Il6 and Ill $2 b$ promoters (Bazzoni et al. 2009; Rossato et al. 2012). miRNAs that regulate transcriptional machinery in this manner have broad yet selective antiinflammatory potential, as they would only attenuate genes that are dependent on a particular coactivator.

\section{CHROMATIN REMODELING AS A TARGET OF miRNA REGULATION}

Although no miRNA has been found which completely recapitulates the LPS tolerance phenotype, several of the examples discussed above show the potential for selective gene regulation and a shift toward antiinflammatory responses in macrophages, affecting TLR signaling, NF$\kappa \mathrm{B}$ subunit expression, and posttranscriptional regulation of Tnf. In other systems, miRNAs also influence two major groups of chromatin regulators identified as likely mediators of tolerization: histone modifying enzymes and nucleosome repositioning machinery.

Table 1. List of microRNAs that are up- or down-regulated following LPS stimulation of monocytes or macrophages.

\begin{tabular}{|c|c|c|c|c|}
\hline & Response to LPS & Cell types tested ${ }^{1}$ & Targets/effects ${ }^{1}$ & References \\
\hline Let-7 family & Up-regulated & BMDM, HPBM & $\begin{array}{l}\text { Down-regulates TLR4 expression; } \\
\text { targets IL-6 in cancer cell lines }\end{array}$ & $\begin{array}{l}\text { Chen et al. (2007); Androulidaki } \\
\text { et al. (2009); Bazzoni et al. } \\
\text { (2009); Iliopoulos et al. (2009) }\end{array}$ \\
\hline miR-9 & Up-regulated & НРBM & $\begin{array}{l}\text { Targets NFKB } 1 / \mathrm{p} 105 \text {; affects } \\
\text { inflammatory gene expression in } \\
\text { other cell types }\end{array}$ & $\begin{array}{l}\text { Bazzoni et al. (2009); Jones et al. } \\
\text { (2009); Gao et al. (2013) }\end{array}$ \\
\hline $\operatorname{miR}-21$ & Up-regulated & $\begin{array}{l}\text { RAW264.7, } \\
\text { BMDM, } \\
\text { PBMC, THP1 }\end{array}$ & $\begin{array}{l}\text { Targets PDCD4; inhibits NF-кB } \\
\text { activation, but increases IL-10 } \\
\text { translation }\end{array}$ & Sheedy et al. (2010) \\
\hline miR-98 & Down-regulated & RAW264.7 & Represses IL-10 production & Liu et al. (2011b) \\
\hline miR-99b & Up-regulated & HPBM & $\begin{array}{l}\text { Targets } \operatorname{Tnf} \text { and } \operatorname{Tnfrsf} 4 \mathrm{mRNA} \text { in } \\
\text { dendritic cells, although protein } \\
\text { levels are not changed }\end{array}$ & $\begin{array}{l}\text { Bazzoni et al. (2009); Singh et al. } \\
\text { (2013) }\end{array}$ \\
\hline miR-125a & Up-regulated & НРBM & Targets A20 in malignant B cells & $\begin{array}{l}\text { Bazzoni et al. (2009); Kim et al. } \\
\text { (2012) }\end{array}$ \\
\hline miR-125b & $\begin{array}{l}\text { Up-regulated in } \\
\text { tolerance, down- } \\
\text { regulated in naïve } \\
\text { LPS response }\end{array}$ & $\begin{array}{l}\text { Tolerized THP1, } \\
\text { RAW264.7 }\end{array}$ & $\begin{array}{l}\text { Suppresses TNF- } \alpha \text { translation; } \\
\text { targets IRF } 4 \text { and enhances } \\
\text { macrophage activation; targets A20 } \\
\text { in malignant B cells }\end{array}$ & $\begin{array}{l}\text { Tili et al. (2007); El Gazzar and } \\
\text { McCall (2010); Chaudhuri et al. } \\
\text { (2011); Kim et al. (2012) }\end{array}$ \\
\hline miR-132 & Up-regulated & THP1, HPBM & Inhibits expression of $\mathrm{p} 300$ & $\begin{array}{l}\text { Taganov et al. (2006); Bazzoni } \\
\text { et al. (2009) }\end{array}$ \\
\hline miR-146a & Up-regulated & $\begin{array}{r}\text { Knockout mice, } \\
\text { THP1, HPBM }\end{array}$ & $\begin{array}{l}\text { Inhibits TLR4 signaling by targeting } \\
\text { IRAK1, TRAF6; mediates } \\
\text { transcriptional and translational } \\
\text { repression of Tnf }\end{array}$ & $\begin{array}{l}\text { Taganov et al. (2006); Bazzoni } \\
\text { et al. (2009); Nahid et al. (2009); } \\
\text { Boldin et al. (2011); El Gazzar } \\
\text { et al. (2011) }\end{array}$ \\
\hline miR-147 & Up-regulated & $\begin{array}{l}\text { Mouse peritoneal } \\
\text { macrophages }\end{array}$ & Inhibits NF- $\kappa \mathrm{B}$ activation & Liu et al. (2009) \\
\hline miR-155 & Up-regulated & THP1, HPBM & Targets SHIP1 and SOCS1 & $\begin{array}{l}\text { Taganov et al. (2006); O'Connell } \\
\text { et al. (2007, 2009); Bazzoni et al. } \\
\text { (2009); Chen et al. (2013) }\end{array}$ \\
\hline miR-187 & Up-regulated & НРBM & $\begin{array}{l}\text { Directly down-regulates TNF- } \alpha \text { and } \\
\text { I } \mathrm{B} \zeta \text {, leading to modestly reduced } \\
\text { IL-6 and IL-12p40 production }\end{array}$ & $\begin{array}{l}\text { Bazzoni et al. (2009); Rossato et al. } \\
\text { (2012) }\end{array}$ \\
\hline miR-221 & Up-regulated & Tolerized THP1 & Targets $\operatorname{Tn} f$ mRNA for degradation & El Gazzar and McCall (2010) \\
\hline $\operatorname{miR}-223$ & Down-regulated & $\begin{array}{l}\text { RAW264.7, } \\
\text { BMDM }\end{array}$ & $\begin{array}{l}\text { Targets STAT3, with downstream } \\
\text { effects on IL- } 6 \text { and IL-1 } \beta\end{array}$ & Chen et al. (2012) \\
\hline miR-579 & Up-regulated & Tolerized THP1 & Suppresses TNF- $\alpha$ translation & El Gazzar and McCall (2010) \\
\hline
\end{tabular}

${ }^{1}$ Cell types that were tested and any observed targets and effects of the miRNA are listed. Effects observed in other cell types are sometimes listed if they may be relevant to the LPS response.

BMDM: Mouse bone marrow-derived macrophages; HPBM, human peripheral blood monocytes; PBMC, human peripheral blood mononuclear cells. 


\section{SWI/SNF Complex as a Regulatory Target}

As SWI/SNF complex recruitment has already been implicated in providing selectivity to gene expression after NF- $\mathrm{KB}$ activation, identification of regulators of this complex may prove fruitful. The SWI/SNF complex may be particularly susceptible to regulation by miRNAs, as function and recruitment of this complex is quite sensitive to small alterations in subunit expression. Homozygous deletion of Brg1 results in embryonic lethality, but even mice heterozygous for $\mathrm{Brg} 1$ deletion are born at lower ratios than expected and have increased incidences of exencephaly and tumors (Bultman et al. 2000, 2008). Proper Brg1 gene dosage is also required for normal cardiac development, and allelic balance between $\mathrm{Brg} 1$ and interacting transcription factors appears to be important for normal expression of some genes (Takeuchi et al. 2011). In an induced signaling system, the glucocorticoid and progesterone receptors seem to compete for available Brg1 to facilitate chromatin remodeling before gene expression, and 2.5-fold overexpression of $\mathrm{Brg} 1$ is sufficient to prevent cross-inhibition (Fryer and Archer 1998). Also of note, in neuronal systems, a switch between expression of SWI/SNF complex members BAF53a and BAF53b is required for proper development. This switch is regulated by miR-9* and miR-124 (Yoo et al. 2009). Thus, dynamic regulation of this complex by RNAs during endotoxin tolerance is an attractive hypothesis.

\section{Histone Modifying Enzymes as a Regulatory Target}

Histone modifications, including H3K14, H4K8, and H4K12 acetylation, can be recognized by Brg1 (Shen et al. 2007). H4 lysine acetylation, in particular, seems to be important for Brg1 recruitment during both the naïve and tolerized LPS response (Saccani et al. 2001; Agalioti et al. 2002; Foster et al. 2007). Other histone modifications may be required for recruitment of transcription factors, including NF-кB p65 (Chan et al. 2005; El Gazzar et al. 2007). miRNAs are predicted to regulate the expression of histone modifying enzymes, and may thereby affect multiple steps of transcriptional initiation. miRNA targeting of these enzymes has in some cases been validated experimentally. For instance, the miR-29 family and miR-290 cluster regulate expression of DNA methyltransferases, and are able to restore expression of silenced genes (Guil and Esteller 2009). miR-22 has also been shown to regulate HDAC4 and HDAC6 in some contexts (Huang et al. 2012; Jovicic et al. 2013). Interestingly, miR-22 has also been found to attenuate NF- $\mathrm{kB}$ activity in hepatocytes by down-regulating expression of an NF- $\mathrm{KB}$ coactivator, NCOA1 (Takata et al. 2011), and miR-29 has been found to influence A20 levels in sarcoma cells (Yaseen Balkhi et al. 2013). This suggests that miRNAs are capable of coordinating changes in NF- $\kappa \mathrm{B}$ activity and chromatin structure. Whether miRNAs regulate changes in gene expression during LPS tolerance through such mechanisms remains to be determined.

\section{Caveats}

It is worth noting, however, that some LPS-inducible miRNAs play opposing roles in the outcome of stimulation. For example, miR-155 and miR-223 are upand down-regulated by LPS stimulation, respectively (O'Connell et al. 2007; Chen et al. 2012). However, unlike the miRNAs discussed above, the resultant levels of these miRNAs leads to increased TNF production and hypersensitivity to LPS shock (Tili et al. 2007; Chen et al. 2012). Furthermore, many of the discussed miRNAs have additional roles in myeloid cell development, and the predominant transcript that is targeted appears to be context-specific (Johnnidis et al. 2008; O'Connell et al. 2008; Boldin et al. 2011; Zhao et al. 2011). Caution may therefore be warranted in extrapolating a miRNA's effect in the tolerization response based on experimental modulation of expression in resting macrophages.

Thus, more thorough methods of screening and study designed to specifically characterize miRNAs involved in endotoxin tolerance are required and may identify regulators that more fully account for this process.

\section{CONCLUSIONS}

Many positive and negative regulators of NF- $\mathrm{KB}$ and LPS stimulation are required to fine-tune an inflammatory response that balances proper containment of infection against the potential for damaging secondary effects. Tolerization may represent an important coordinated mechanism to address this predicament, dampening the initial proinflammatory response to prevent overwhelming septic shock, while at the same time increasing production of antimicrobial peptides to prevent susceptibility to secondary infection afterward. Chromatin modifications likely play a key role in this response, working in concert with signaling changes to differentially recruit NF- $\mathrm{BB}$ subunits and transcriptional machinery to gene promoters before and during secondary challenge.

The potential therapeutic benefits of understanding this system are showed by a recent study which found that synthetic histone mimetics can inhibit bromodomain protein recruitment to late response promoters during the LPS response, selectively abolishing expression of those genes. Intriguingly, this greatly improved septic shock survival of mice even if the inhibitor was introduced after LPS administration (Nicodeme et al. 2010), whereas other potential treatments such as IL-10 administration lose efficacy within a few hours of shock initiation (Berg et al. 1995). This advantage makes treatments based on the concept of modulating histone modification far more practical for clinical use.

Knockout and overexpression models have clearly showed that miRNAs can play essential roles in many processes, including embryonic development, development of hematopoietic lineages, and the generation of T- and B-cell responses. Importantly, they regulate chromatin changes similar to those central to the LPS response, suggesting a potential role for miRNAs in 
LPS tolerization. Integrating these regulators into tolerization models may allow for further development of selective therapeutics to ameliorate or even prevent septic shock, which has remained intractable to in vivo manipulation.

\section{REFERENCES}

Agalioti T, Chen G, Thanos D. 2002. Deciphering the transcriptional histone acetylation code for a human gene. Cell 111: 381-392.

Androulidaki A, Iliopoulos D, Arranz A, Doxaki C, Schworer S, Zacharioudaki V, Margioris AN, Tsichlis PN, Tsatsanis C. 2009. The kinase Akt1 controls macrophage response to lipopolysaccharide by regulating microRNAs. Immunity 31: 220-231.

Angus DC, Linde-Zwirble WT, Lidicker J, Clermont G, Carcillo J, Pinsky MR. 2001. Epidemiology of severe sepsis in the United States: Analysis of incidence, outcome, and associated costs of care. Crit Care Med 29: 1303-1310.

Bartel DP. 2009. MicroRNAs: Target recognition and regulatory functions. Cell 136: 215-233.

Bazzoni F, Rossato M, Fabbri M, Gaudiosi D, Mirolo M, Mori L, Tamassia N, Mantovani A, Cassatella MA, Locati M. 2009. Induction and regulatory function of miR-9 in human monocytes and neutrophils exposed to proinflammatory signals. Proc Natl Acad Sci 106: 5282-5287.

Beeson PB, Technical Assistance of Elizabeth R. 1947. Tolerance to bacterial pyrogens: I. Factors influencing its development. J Exp Med 86: 29-38.

Berg DJ, Kuhn R, Rajewsky K, Muller W, Menon S, Davidson N, Grunig G, Rennick D. 1995. Interleukin-10 is a central regulator of the response to LPS in murine models of endotoxic shock and the Shwartzman reaction but not endotoxin tolerance. J Clin Invest 96: 2339-2347.

Bohuslav J, Kravchenko VV, Parry GC, Erlich JH, Gerondakis S, Mackman N, Ulevitch RJ. 1998. Regulation of an essential innate immune response by the p50 subunit of NF-кB. J Clin Invest 102: 1645-1652.

Boldin MP, Taganov KD, Rao DS, Yang L, Zhao JL, Kalwani M, Garcia-Flores Y, Luong M, Devrekanli A, Xu J, et al. 2011. miR-146a is a significant brake on autoimmunity, myeloproliferation, and cancer in mice. J Exp Med 208: 1189-1201.

Boone DL, Turer EE, Lee EG, Ahmad RC, Wheeler MT, Tsui C, Hurley P, Chien M, Chai S, Hitotsumatsu O, et al. 2004. The ubiquitin-modifying enzyme A20 is required for termination of Toll-like receptor responses. Nat Immunol 5: 1052-1060.

Bosisio D, Polentarutti N, Sironi M, Bernasconi S, Miyake K, Webb GR, Martin MU, Mantovani A, Muzio M. 2002. Stimulation of toll-like receptor 4 expression in human mononuclear phagocytes by interferon- $\gamma$ : A molecular basis for priming and synergism with bacterial lipopolysaccharide. Blood 99: 3427-3431.

Bultman S, Gebuhr T, Yee D, La Mantia C, Nicholson J, Gilliam A, Randazzo F, Metzger D, Chambon P, Crabtree G, et al. 2000. A Brg1 null mutation in the mouse reveals functional differences among mammalian SWI/SNF complexes. Mol Cell 6: $1287-1295$.

Bultman SJ, Herschkowitz JI, Godfrey V, Gebuhr TC, Yaniv M, Perou CM, Magnuson T. 2008. Characterization of mammary tumors from Brg1 heterozygous mice. Oncogene 27: 460468.

Carey FJ, Braude AI, Zalesky M. 1958. Studies with radioactive endotoxin. III. The effect of tolerance on the distribution of radioactivity after intravenous injection of Escherichia coli endotoxin labeled with Cr51. J Clin Invest 37: 441-457.

Cavaillon J-M, Pitton C, Fitting C. 1994. Endotoxin tolerance is not a LPS-specific phenomenon: Partial mimicry with IL-1, IL-10 and TGF $\beta$. J Endotoxin Res 1: 21-29.

Chai Z, Gatti S, Toniatti C, Poli V, Bartfai T. 1996. Interleukin (IL)-6 gene expression in the central nervous system is nec- essary for fever response to lipopolysaccharide or IL-1 $\beta$ : A study on IL-6-deficient mice. J Exp Med 183: 311-316.

Chan C, Li L, McCall CE, Yoza BK. 2005. Endotoxin tolerance disrupts chromatin remodeling and NF- $\mathrm{KB}$ transactivation at the IL-1 $\beta$ promoter. J Immunol 175: 461-468.

Chaudhuri AA, So AY, Sinha N, Gibson WS, Taganov KD, O'Connell RM, Baltimore D. 2011. MicroRNA-125b potentiates macrophage activation. J Immunol 187: 50625068 .

Chen J, Ivashkiv LB. 2010. IFN- $\gamma$ abrogates endotoxin tolerance by facilitating Toll-like receptor-induced chromatin remodeling. Proc Natl Acad Sci 107: 19438-19443.

Chen XM, Splinter PL, O'Hara SP, LaRusso NF. 2007. A cellular micro-RNA, let-7i, regulates Toll-like receptor 4 expression and contributes to cholangiocyte immune responses against Cryptosporidium parvum infection. J Biol Chem 282: 28929-28938.

Chen X, El Gazzar M, Yoza BK, McCall CE. 2009. The NF-кB factor RelB and histone H3 lysine methyltransferase G9a directly interact to generate epigenetic silencing in endotoxin tolerance. J Biol Chem 284: 27857-27865.

Chen Q, Wang H, Liu Y, Song Y, Lai L, Han Q, Cao X, Wang Q. 2012. Inducible microRNA-223 down-regulation promotes TLR-triggered IL- 6 and IL-1 $\beta$ production in macrophages by targeting STAT3. PLoS One 7: e42971.

Chen Y, Liu W, Sun T, Huang Y, Wang Y, Deb DK, Yoon D, Kong J, Thadhani R, Li YC. 2013. 1,25-Dihydroxyvitamin D promotes negative feedback regulation of TLR signaling via targeting microRNA-155-SOCS1 in macrophages. J Immunol 190: $3687-3695$.

El Gazzar M, McCall CE. 2010. MicroRNAs distinguish translational from transcriptional silencing during endotoxin tolerance. J Biol Chem 285: 20940-20951.

El Gazzar M, Yoza BK, Hu JY, Cousart SL, McCall CE. 2007. Epigenetic silencing of tumor necrosis factor $\alpha$ during endotoxin tolerance. J Biol Chem 282: 26857-26864.

El Gazzar M, Church A, Liu T, McCall CE. 2011. MicroRNA146a regulates both transcription silencing and translation disruption of TNF- $\alpha$ during TLR4-induced gene reprogramming. J Leukocyte Biol 90: 509-519.

Erroi A, Fantuzzi G, Mengozzi M, Sironi M, Orencole SF, Clark BD, Dinarello CA, Isetta A, Gnocchi P, Giovarelli M, et al. 1993. Differential regulation of cytokine production in lipopolysaccharide tolerance in mice. Infect Immun 61: 43564359 .

Fabian MR, Sonenberg N. 2012. The mechanics of miRNAmediated gene silencing: A look under the hood of miRISC. Nat Struct Mol Biol 19: 586-593.

Favorite GO, Morgan HR. 1942. Effects produced by the intravenous injection in man of a toxic antigenic material derived from Eberthella typhosa: Clinical, hematological, chemical and serological studies. J Clin Invest 21: 589-599.

Flach R, Flohe S, Laschinski M, Hofmann K, Kreuzfelder E, Schade FU. 1997. Interleukin-10 is downregulated in mononuclear cells from endotoxin tolerant humans. $J$ Endotoxin Res 4: 189-195.

Flohe S, Dominguez Fernandez E, Ackermann M, Hirsch T, Borgermann J, Schade FU. 1999. Endotoxin tolerance in rats: Expression of TNF- $\alpha$, IL-6, IL-10, VCAM-1 AND HSP 70 in lung and liver during endotoxin shock. Cytokine 11: 796-804.

Foster SL, Hargreaves DC, Medzhitov R. 2007. Gene-specific control of inflammation by TLR-induced chromatin modifications. Nature 447: 972-978.

Fraker DL, Stovroff MC, Merino MJ, Norton JA. 1988. Tolerance to tumor necrosis factor in rats and the relationship to endotoxin tolerance and toxicity. J Exp Med 168: $95-105$.

Frankenberger M, Pechumer H, Ziegler-Heitbrock HW. 1995. Interleukin-10 is upregulated in LPS tolerance. J Inflamm 45: $56-63$.

Freudenberg MA, Galanos C. 1988. Induction of tolerance to lipopolysaccharide (LPS)-D-galactosamine lethality by pre- 
treatment with LPS is mediated by macrophages. Infect Immun 56: 1352-1357.

Freudenberg MA, Keppler D, Galanos C. 1986. Requirement for lipopolysaccharide-responsive macrophages in galactosamine-induced sensitization to endotoxin. Infect Immun 51: $891-895$.

Fryer CJ, Archer TK. 1998. Chromatin remodelling by the glucocorticoid receptor requires the BRG1 complex. Nature 393: 88-91.

Gao F, Zhao ZL, Zhao WT, Fan QR, Wang SC, Li J, Zhang YQ, Shi JW, Lin XL, Yang S, et al. 2013. miR-9 modulates the expression of interferon-regulated genes and MHC class I molecules in human nasopharyngeal carcinoma cells. Biochem Biophys Res Commun 431: 610-616.

Guil S, Esteller M. 2009. DNA methylomes, histone codes and miRNAs: Tying it all together. Int J Biochem Cell Biol 41: 87-95.

Haas JG, Baeuerle PA, Riethmuller G, Ziegler-Heitbrock HW. 1990. Molecular mechanisms in down-regulation of tumor necrosis factor expression. Proc Natl Acad Sci 87: 95639567.

Hall MJ, Williams SN, DeFrances CJ, Golosinskiy A. 2011. Inpatient care for septicemia or sepsis: A challenge for patients and hospitals. NCHS Data Brief 2011: 1-8.

Hargreaves DC, Horng T, Medzhitov R. 2009. Control of inducible gene expression by signal-dependent transcriptional elongation. Cell 138: 129-145.

Hayden MS, Ghosh S. 2012. NF-кB, the first quarter-century: Remarkable progress and outstanding questions. Genes Dev 26: $203-234$.

Henricson BE, Manthey CL, Perera PY, Hamilton TA, Vogel SN. 1993. Dissociation of lipopolysaccharide (LPS)-inducible gene expression in murine macrophages pretreated with smooth LPS versus monophosphoryl lipid A. Infect Immun 61: $2325-2333$.

Hoffmann A, Natoli G, Ghosh G. 2006. Transcriptional regulation via the NF-кB signaling module. Oncogene 25: $6706-$ 6716.

Huang S, Wang S, Bian C, Yang Z, Zhou H, Zeng Y, Li H, Han Q, Zhao RC. 2012. Upregulation of miR-22 promotes osteogenic differentiation and inhibits adipogenic differentiation of human adipose tissue-derived mesenchymal stem cells by repressing HDAC6 protein expression. Stem Cells Dev 21: $2531-2540$

Iliopoulos D, Hirsch HA, Struhl K. 2009. An epigenetic switch involving NF- $\kappa \mathrm{B}$, Lin28, Let-7 MicroRNA, and IL6 links inflammation to cell transformation. Cell 139: 693-706.

Jiang Z, Georgel P, Du X, Shamel L, Sovath S, Mudd S, Huber M, Kalis C, Keck S, Galanos C, et al. 2005. CD14 is required for MyD88-independent LPS signaling. Nat Immunol 6: $565-570$.

Johnnidis JB, Harris MH, Wheeler RT, Stehling-Sun S, Lam MH, Kirak O, Brummelkamp TR, Fleming MD, Camargo FD. 2008. Regulation of progenitor cell proliferation and granulocyte function by microRNA-223. Nature 451: 1125-1129.

Jones SW, Watkins G, Le Good N, Roberts S, Murphy CL, Brockbank SM, Needham MR, Read SJ, Newham P. 2009. The identification of differentially expressed microRNA in osteoarthritic tissue that modulate the production of TNF- $\alpha$ and MMP13. Osteoarthritis Cartilage 17: 464-472.

Jovicic A, Zaldivar Jolissaint JF, Moser R, Silva Santos Mde F, Luthi-Carter R. 2013. MicroRNA-22 (miR-22) overexpression is neuroprotective via general anti-apoptotic effects and may also target specific Huntington's disease-related mechanisms. PLoS One 8: e54222.

Kayama H, Ramirez-Carrozzi VR, Yamamoto M, Mizutani T, Kuwata H, Iba H, Matsumoto M, Honda K, Smale ST, Takeda K. 2008. Class-specific regulation of pro-inflammatory genes by MyD88 pathways and ІкBל. J Biol Chem 283: $12468-$ 12477.

Kim SW, Ramasamy K, Bouamar H, Lin AP, Jiang D, Aguiar RC. 2012. MicroRNAs miR-125a and miR-125b constitutively activate the NF- $\kappa \mathrm{B}$ pathway by targeting the tumor necrosis factor $\alpha$-induced protein 3 (TNFAIP3, A20). Proc Natl Acad Sci 109: 7865-7870.

Knopf HP, Otto F, Engelhardt R, Freudenberg MA, Galanos C, Herrmann F, Schumann RR. 1994. Discordant adaptation of human peritoneal macrophages to stimulation by lipopolysaccharide and the synthetic lipid A analogue SDZ MRL 953. Down-regulation of TNF- $\alpha$ and IL-6 is paralleled by an up-regulation of IL- $1 \beta$ and granulocyte colony-stimulating factor expression. J Immunol 153: 287-299.

Kobayashi K, Hernandez LD, Galan JE, Janeway CA Jr, Medzhitov R, Flavell RA. 2002. IRAK-M is a negative regulator of Toll-like receptor signaling. Cell 110: 191-202.

Lagos D, Pollara G, Henderson S, Gratrix F, Fabani M, Milne RS, Gotch F, Boshoff C. 2010. miR-132 regulates antiviral innate immunity through suppression of the p300 transcriptional co-activator. Nat Cell Biol 12: 513-519.

Lang CH, Spitzer JA. 1987. Glucose kinetics and development of endotoxin tolerance during long-term continuous endotoxin infusion. Metabolism 36: 469-474.

LaRue KE, McCall CE. 1994. A labile transcriptional repressor modulates endotoxin tolerance. $J$ Exp Med 180: 2269-2275.

Lehner MD, Ittner J, Bundschuh DS, van Rooijen N, Wendel A, Hartung T. 2001a. Improved innate immunity of endotoxintolerant mice increases resistance to Salmonella enterica serovar typhimurium infection despite attenuated cytokine response. Infect Immun 69: 463-471.

Lehner MD, Morath S, Michelsen KS, Schumann RR, Hartung T. 2001b. Induction of cross-tolerance by lipopolysaccharide and highly purified lipoteichoic acid via different Toll-like receptors independent of paracrine mediators. J Immunol 166: $5161-5167$.

Li P, Allen H, Banerjee S, Franklin S, Herzog L, Johnston C, McDowell J, Paskind M, Rodman L, Salfeld J, et al. 1995. Mice deficient in IL-1 $\beta$-converting enzyme are defective in production of mature IL-1 $\beta$ and resistant to endotoxic shock. Cell 80: 401-411.

Liu G, Friggeri A, Yang Y, Park YJ, Tsuruta Y, Abraham E. 2009. miR-147, a microRNA that is induced upon Toll-like receptor stimulation, regulates murine macrophage inflammatory responses. Proc Natl Acad Sci 106: 15819-15824.

Liu TF, Yoza BK, El Gazzar M, Vachharajani VT, McCall CE. 2011a. NAD+-dependent SIRT1 deacetylase participates in epigenetic reprogramming during endotoxin tolerance. J Biol Chem 286: 9856-9864.

Liu Y, Chen Q, Song Y, Lai L, Wang J, Yu H, Cao X, Wang Q. 2011b. MicroRNA-98 negatively regulates IL-10 production and endotoxin tolerance in macrophages after LPS stimulation. FEBS Lett 585: 1963-1968.

Medvedev AE, Kopydlowski KM, Vogel SN. 2000. Inhibition of lipopolysaccharide-induced signal transduction in endotoxin-tolerized mouse macrophages: Dysregulation of cytokine, chemokine, and toll-like receptor 2 and 4 gene expression. J Immunol 164: 5564-5574.

Medvedev AE, Henneke P, Schromm A, Lien E, Ingalls R, Fenton MJ, Golenbock DT, Vogel SN. 2001. Induction of tolerance to lipopolysaccharide and mycobacterial components in Chinese hamster ovary/CD14 cells is not affected by overexpression of Toll-like receptors 2 or 4 . J Immunol 167: $2257-2267$.

Medvedev AE, Lentschat A, Wahl LM, Golenbock DT, Vogel SN. 2002. Dysregulation of LPS-induced Toll-like receptor 4-MyD88 complex formation and IL-1 receptor-associated kinase 1 activation in endotoxin-tolerant cells. $J$ Immunol 169: 5209-5216.

Morgan HR. 1941. Immunologic properties of an antigenic material isolated from Eberthella typhosa. J Immunol 41: 161180

Munford RS, Pugin J. 2001. Normal responses to injury prevent systemic inflammation and can be immunosuppressive. Am J Respir Crit Care Med 163: 316-321.

Munoz C, Carlet J, Fitting C, Misset B, Bleriot JP, Cavaillon JM. 1991. Dysregulation of in vitro cytokine production by monocytes during sepsis. J Clin Invest 88: 1747-1754. 
Myers RD, Rudy TA, Yaksh TL. 1974. Fever produced by endotoxin injected into the hypothalamus of the monkey and its antagonism by salicylate. J Physiol 243: 167-193.

Nahid MA, Pauley KM, Satoh M, Chan EK. 2009. miR-146a is critical for endotoxin-induced tolerance: Implication in innate immunity. J Biol Chem 284: 34590-34599.

Nicodeme E, Jeffrey KL, Schaefer U, Beinke S, Dewell S, Chung CW, Chandwani R, Marazzi I, Wilson P, Coste H, et al. 2010. Suppression of inflammation by a synthetic histone mimic. Nature 468: 1119-1123.

Nomura F, Akashi S, Sakao Y, Sato S, Kawai T, Matsumoto M, Nakanishi K, Kimoto M, Miyake K, Takeda K, et al. 2000. Cutting edge: Endotoxin tolerance in mouse peritoneal macrophages correlates with down-regulation of surface toll-like receptor 4 expression. J Immunol 164: 3476-3479.

O'Connell RM, Taganov KD, Boldin MP, Cheng G, Baltimore D. 2007. MicroRNA-155 is induced during the macrophage inflammatory response. Proc Natl Acad Sci 104: 1604-1609.

O'Connell RM, Rao DS, Chaudhuri AA, Boldin MP, Taganov KD, Nicoll J, Paquette RL, Baltimore D. 2008. Sustained expression of microRNA-155 in hematopoietic stem cells causes a myeloproliferative disorder. J Exp Med 205: 585-594.

O'Connell RM, Chaudhuri AA, Rao DS, Baltimore D. 2009. Inositol phosphatase SHIP1 is a primary target of miR-155. Proc Natl Acad Sci 106: 7113-7118.

Pasquinelli AE. 2012. MicroRNAs and their targets: Recognition, regulation and an emerging reciprocal relationship. Nat Rev Genet 13: 271-282.

Porta C, Rimoldi M, Raes G, Brys L, Ghezzi P, Di Liberto D, Dieli F, Ghisletti S, Natoli G, De Baetselier P, et al. 2009. Tolerance and M2 (alternative) macrophage polarization are related processes orchestrated by $\mathrm{p} 50$ nuclear factor $\mathrm{\kappa B}$. Proc Natl Acad Sci 106: 14978-14983.

Ramirez-Carrozzi VR, Nazarian AA, Li CC, Gore SL, Sridharan R, Imbalzano AN, Smale ST. 2006. Selective and antagonistic functions of SWI/SNF and Mi-2 $\beta$ nucleosome remodeling complexes during an inflammatory response. Genes Dev 20: $282-296$.

Ramirez-Carrozzi VR, Braas D, Bhatt DM, Cheng CS, Hong C, Doty KR, Black JC, Hoffmann A, Carey M, Smale ST. 2009. A unifying model for the selective regulation of inducible transcription by $\mathrm{CpG}$ islands and nucleosome remodeling. Cell 138: $114-128$.

Randow F, Syrbe U, Meisel C, Krausch D, Zuckermann H, Platzer C, Volk HD. 1995. Mechanism of endotoxin desensitization: Involvement of interleukin 10 and transforming growth factor $\beta$. J Exp Med 181: 1887-1892.

Rayhane N, Fitting C, Lortholary O, Dromer F, Cavaillon JM. 2000. Administration of endotoxin associated with lipopolysaccharide tolerance protects mice against fungal infection. Infect Immun 68: 3748-3753.

Rossato M, Curtale G, Tamassia N, Castellucci M, Mori L, Gasperini S, Mariotti B, De Luca M, Mirolo M, Cassatella MA, et al. 2012. IL-10-induced microRNA-187 negatively regulates TNF- $\alpha$, IL-6, and IL-12p40 production in TLR4-stimulated monocytes. Proc Natl Acad Sci 109: E3101-E3110.

Roth J, McClellan JL, Kluger MJ, Zeisberger E. 1994. Attenuation of fever and release of cytokines after repeated injections of lipopolysaccharide in guinea-pigs. J Physiol 477: $177-185$.

Rothe J, Lesslauer W, Lotscher H, Lang Y, Koebel P, Kontgen F, Althage A, Zinkernagel R, Steinmetz M, Bluethmann H. 1993. Mice lacking the tumour necrosis factor receptor 1 are resistant to TNF-mediated toxicity but highly susceptible to infection by Listeria monocytogenes. Nature 364: $798-$ 802.

Saccani S, Pantano S, Natoli G. 2001. Two waves of nuclear factor $\mathrm{\kappa B}$ recruitment to target promoters. $J$ Exp Med 193: $1351-1359$.

Sato S, Nomura F, Kawai T, Takeuchi O, Muhlradt PF, Takeda K, Akira S. 2000. Synergy and cross-tolerance between tolllike receptor (TLR) 2- and TLR4-mediated signaling pathways. J Immunol 165: 7096-7101.
Sheedy FJ, Palsson-McDermott E, Hennessy EJ, Martin C, O'Leary JJ, Ruan Q, Johnson DS, Chen Y, O'Neill LA. 2010. Negative regulation of TLR4 via targeting of the proinflammatory tumor suppressor PDCD4 by the microRNA miR-21. Nat Immunol 11: 141-147.

Shen W, Xu C, Huang W, Zhang J, Carlson JE, Tu X, Wu J, Shi Y. 2007. Solution structure of human Brg1 bromodomain and its specific binding to acetylated histone tails. Biochemistry 46: $2100-2110$.

Singh Y, Kaul V, Mehra A, Chatterjee S, Tousif S, Dwivedi VP, Suar M, Van Kaer L, Bishai WR, Das G. 2013. Mycobacterium tuberculosis controls microRNA-99b (miR-99b) expression in infected murine dendritic cells to modulate host immunity. J Biol Chem 288: 5056-5061.

Soong J, Soni N. 2012. Sepsis: Recognition and treatment. Clin Med 12: 276-280.

Taganov KD, Boldin MP, Chang KJ, Baltimore D. 2006. NF$\mathrm{\kappa B}$-dependent induction of microRNA miR-146, an inhibitor targeted to signaling proteins of innate immune responses. Proc Natl Acad Sci 103: 12481-12486.

Takata A, Otsuka M, Kojima K, Yoshikawa T, Kishikawa T, Yoshida H, Koike K. 2011. MicroRNA-22 and microRNA-140 suppress NF- $\kappa \mathrm{B}$ activity by regulating the expression of NF- $\kappa \mathrm{B}$ coactivators. Biochem Biophys Res Commun 411: 826-831.

Takeuchi JK, Lou X, Alexander JM, Sugizaki H, DelgadoOlguin P, Holloway AK, Mori AD, Wylie JN, Munson C, Zhu Y, et al. 2011. Chromatin remodelling complex dosage modulates transcription factor function in heart development. Nat Commun 2: 187.

Tili E, Michaille JJ, Cimino A, Costinean S, Dumitru CD, Adair B, Fabbri M, Alder H, Liu CG, Calin GA, et al. 2007. Modulation of miR-155 and miR-125b levels following lipopolysaccharide/TNF- $\alpha$ stimulation and their possible roles in regulating the response to endotoxin shock. J Immunol 179: 5082-5089.

Tracey KJ, Beutler B, Lowry SF, Merryweather J, Wolpe S, Milsark IW, Hariri RJ, Fahey TJ III, Zentella A, Albert JD, et al. 1986. Shock and tissue injury induced by recombinant human cachectin. Science 234: 470-474.

Virca GD, Kim SY, Glaser KB, Ulevitch RJ. 1989. Lipopolysaccharide induces hyporesponsiveness to its own action in RAW 264.7 cells. J Biol Chem 264: 21951-21956.

Wahlstrom K, Bellingham J, Rodriguez JL, West MA. 1999. Inhibitory $\kappa \mathrm{B} \alpha$ control of nuclear factor- $\mathrm{\kappa} \mathrm{B}$ is dysregulated in endotoxin tolerant macrophages. Shock 11: 242-247.

Weinmann AS, Plevy SE, Smale ST. 1999. Rapid and selective remodeling of a positioned nucleosome during the induction of IL-12 p40 transcription. Immunity 11: 665-675.

Welty-Wolf KE, Carraway MS, Huang YC, Simonson SG, Kantrow SP, Piantadosi CA. 1998. Bacterial priming increases lung injury in gram-negative sepsis. Am J Respir Crit Care Med 158: 610-619.

Wheeler DS, Lahni PM, Denenberg AG, Poynter SE, Wong HR, Cook JA, Zingarelli B. 2008. Induction of endotoxin tolerance enhances bacterial clearance and survival in murine polymicrobial sepsis. Shock 30: 267-273.

Wysocka M, Robertson S, Riemann H, Caamano J, Hunter C, Mackiewicz A, Montaner LJ, Trinchieri G, Karp CL. 2001. IL-12 suppression during experimental endotoxin tolerance: Dendritic cell loss and macrophage hyporesponsiveness. $J$ Immunol 166: 7504-7513.

Xiong Y, Medvedev AE. 2011. Induction of endotoxin tolerance in vivo inhibits activation of IRAK4 and increases negative regulators IRAK-M, SHIP-1, and A20. J Leukocyte Biol 90: $1141-1148$.

Xiong Y, Qiu F, Piao W, Song C, Wahl LM, Medvedev AE. 2011. Endotoxin tolerance impairs IL-1 receptor-associated kinase (IRAK) 4 and TGF- $\beta$-activated kinase 1 activation, K63-linked polyubiquitination and assembly of IRAK1, TNF receptor-associated factor 6 , and IКB kinase $\gamma$ and increases A20 expression. J Biol Chem 286: 7905-7916.

Yamamoto M, Yamazaki S, Uematsu S, Sato S, Hemmi H, Hoshino K, Kaisho T, Kuwata H, Takeuchi O, Takeshige K, 
et al. 2004. Regulation of Toll/IL-1-receptor-mediated gene expression by the inducible nuclear protein IкB $\zeta$. Nature 430: 218-222.

Yaseen Balkhi M, Iwenofu OH, Bakkar N, Ladner KJ, Chandler DS, Houghton PJ, London CA, Kraybill W, Perrotti D, Croce CM, et al. 2013. miR-29 acts as a decoy in sarcomas to protect the tumor suppressor A20 mRNA from degradation by HuR. Sci Signal 6: ra63.

Yoo AS, Staahl BT, Chen L, Crabtree GR. 2009. MicroRNAmediated switching of chromatin-remodelling complexes in neural development. Nature 460: 642-646.

Yoza BK, Hu JY, Cousart SL, McCall CE. 2000. Endotoxin inducible transcription is repressed in endotoxin tolerant cells. Shock 13: 236-243.

Yoza BK, Hu JY, Cousart SL, Forrest LM, McCall CE. 2006. Induction of RelB participates in endotoxin tolerance. $J$ Immunol 177: 4080-4085.
Zhang X, Morrison DC. 1993. Lipopolysaccharide-induced selective priming effects on tumor necrosis factor $\alpha$ and nitric oxide production in mouse peritoneal macrophages. $J$ Exp Med 177: 511-516.

Zhao JL, Rao DS, Boldin MP, Taganov KD, O’Connell RM, Baltimore D. 2011. NF- $\kappa$ B dysregulation in microRNA146a-deficient mice drives the development of myeloid malignancies. Proc Natl Acad Sci 108: 9184-9189.

Ziegler-Heitbrock HW, Wedel A, Schraut W, Strobel M, Wendelgass P, Sternsdorf T, Bauerle PA, Haas JG, Riethmuller G. 1994. Tolerance to lipopolysaccharide involves mobilization of nuclear factor $\mathrm{\kappa B}$ with predominance of $\mathrm{p} 50$ homodimers. $J$ Biol Chem 269: 17001-17004.

Zuckerman SH, Evans GF, Snyder YM, Roeder WD. 1989. Endotoxin-macrophage interaction: Post-translational regulation of tumor necrosis factor expression. J Immunol 143: $1223-1227$. 


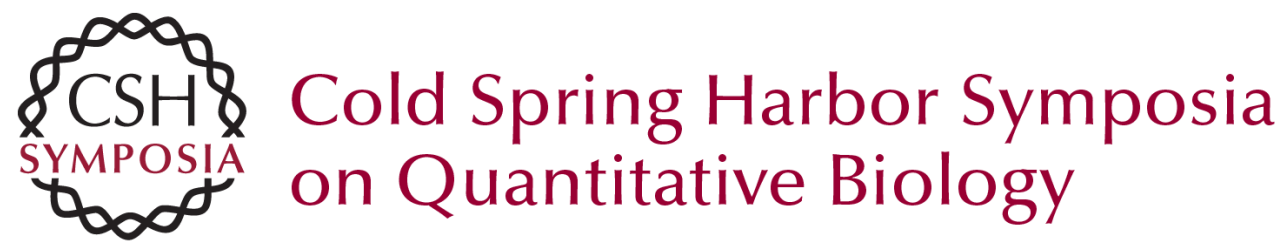

\section{Tolerization of Inflammatory Gene Expression}

John J. Seeley and Sankar Ghosh

Cold Spring Harb Symp Quant Biol 2013 78: 69-79 originally published online January 7, 2014 Access the most recent version at doi:10.1101/sqb.78.020040

References This article cites 114 articles, 58 of which can be accessed free at: http://symposium.cshlp.org/content/78/69.full.html\#ref-list-1

\section{License}

Email Alerting Receive free email alerts when new articles cite this article - sign up in Service the box at the top right corner of the article or click here. 